Vol. 11 No. 22020

e-issn : 2622-0148, p-issn : 2087-0035

\title{
STUDI LITERATUR PENGARUH SLOW DEEP BREATHING (SDB) TERHADAP KADAR GULA DARAH PADA PENDERITA DIABETES MELITUS TIPE 2
}

Literature Study Of The Effect Of Slow Deep Breathing (SDB) On Blood Sugar Levels In Type 2 Diabetes Mellitus

\author{
Maryati Tombokan, Muhammad Ardi, Fitria Hamka, Ambo Dalle \\ Poltekkes Kemenkes Makassar \\ Email : maryatitombokan@gmail.com
}

\begin{abstract}
Slow Deep Brathing is combined method of slow breath and deep breath that can make relaxation increase, and is a form of therapy used to accompany therapy conventional (medical). The purpose of this literature study is to identify recommendations for the influence of Slow Deep Breathing (SDB) on blood sugar levels in people with DM Type 2. Data collection is done by using library studies, by searching for the results of scientific publications in the period 20152020 by using google scholar that matches the criteria of the results specified. The results of the literature study from the 7 journals obtained, can be concluded that there is an influence of Slow Deep Breathing on the decrease in sugar levels in the blood after $\geq 10$ minutes for $2 x$ a day and can be done $\leq 10$ minutes but combined with therapy Progresive Muscle Relaxation (PMR) or with therapy murottal surah Ar-Rahman.
\end{abstract}

Keywords: Blood Sugar Levels, Diabetes Mellitus, Slow Deep Breathing

\section{ABSTRAK}

Slow Deep Brathing merupakan metode gabungan dari napas lambat dan napas dalam yang dapat membuat relaksasi meningkat, dan merupakan bentuk terapi yang dapat digunakan untuk mendampingi terapi konvensional (medis). Tujuan dari studi literatur ini adalah untuk mengidentifikasi rekomendasi pengaruh Slow Deep Breathing (SDB) terhadap kadar gula darah pada penderita DM tipe 2. Pengumpulan data dilakukan dengan menggunakan studi pustaka, dengan cara menelusuri hasil publikasi ilmiah dalam rentang waktu tahun 2015-2020 dengan memakai google scholar yang sesuai dengan kriteria hasil yang ditentukan. Hasil studi literatur dari ke-7 jurnal yang di dapatkan, dapat ditarik kesimpulan bahwa ada pengaruh Slow Deep Breathing terhadap penurunan kadar gula di dalam darah setelah dilakukan $\geq 10$ menit selama $2 x$ sehari dan dapat dilakukan $\leq 10$ menit tetapi dikombinasikan dengan terapi Progresive Muscle Relaxation (PMR) atau dengan terapi murottal surah Ar-Rahman.

Kata Kunci : Kadar gula darah, Diabetes Melitus, Slow Deep Breathing

\section{Pendahuluan}

Diabetes Melitus adalah penyakit kronis dan membutuhkan perawatan medis segera. Edukasi dan dukungan manajemen diri pasien yang segera sangat penting agar mencegah terjadinya komplikasi akut maupun komplikasi kronik (ADA, 2019). Diabetes Melitus dapat terjadi karena insulin yang diproduksi tidak mampu lagi untuk mempertahankan kadar gula di dalam darah dalam keadaan normal (Soegondo, dkk, 2018). Saat ini, Diabetes Melitus tercatat sebagai urutan ke-4 dari masalah nasional untuk penyakit degeneratif setelah serebrovaskuler, kardiovaskuler, dan geriatrik (Jauhari, 2016 dalam Syarif, 2019).

Pada tahun 2019, terdapat 463 juta orang (Usia 2079 tahun) diseluruh dunia hidup dengan penyakit Diabetes Melitus. Diperkirakan pada tahun 2045, akan meningkat sampai 700 juta orang penderita. Negara Indonesia sendiri untuk penderita Diabetes Melitus menduduki peringkat ke-7 di dunia setelah Jerman, Pakistan, Brazil, Amerika Serikat, Bangladesh, Meksiko, Cina, Mesir, dan India. Prevalensi di
Indonesia untuk penyakit DM dari beberapa tahun ini mengalami peningkatan yaitu pada tahun 2010 sebanyak 6,9 juta penderita dan pada tahun 2019 menjadi sebanyak 10,7 juta orang penderita, dan diperkirakan pada tahun 2045 akan terjadi peningkatan hingga 16,7 juta orang penderita. ( IDF, 2019)

Di Indonesia pada tahun 2018 dari 34 provinsi, Sulawesi Selatan menduduki peringkat ke 17 untuk penderita Diabetes terbanyak yaitu sebanyak 1,8\% (Riskesdas, 2018). Kasus Diabetes Melitus sendiri di Makassar pada tahun 2017 di 46 puskesmas yaitu 6.106 kasus DM. (Dinas Kesehatan Kota Makassar, 2018).

Angka penderita Diabetes yang semakin meningkat dapat diakibatkan karena berbagai faktor misalkan faktor obesitas, usia, infeksi, keturunan, obat-obatan, kurang gerak badan, ras atau etnis, stres, dan kehamilan. Diabetes Melitus identik dengan meningkatnya kadar gula di dalam darah. Jika penderita diabetes mempunyai gula darah yang tinggi 
atau tidak terkendali dalam waktu yang lama, maka penderita dapat menghadapi berbagai macam komplikasi Diabetes Melitus misalkan gagal jantung, kebutaan, gagal ginjal, atau bahkan sampai kematian. Glukosa adalah gula sederhana yang berfungsi sebagai sumber energi di dalam tubuh.

Penatalaksanaan Diabetes untuk mengendalikan kadar gula di dalam darah ada 4 cara yaitu dengan pendidikan cara manajemen diabetes mandiri, terapi obat (farmakologi) dan terapi komplementer (Nonfarmakologi), aktifitas fisik, terapi gizi dan nutrisi. Terapi komplementer adalah suatu terapi yang sifatnya sebagai pengobatan alami yang dapat mempercepat penyembuhan untuk tubuh, dan mampu menangani penyebab dari penyakit. Terapi komplementer juga telah diakui dan mampu digunakan untuk mendampingi terapi medis/konvensional. Terapi komplementer yang dapat digunakan dalam mengendalikan kadar gula didalam darah salah satunya yaitu terapi Slow Deep Breathing (SDB).

Slow Deep Brathing merupakan metode gabungan dari napas lambat dan napas dalam yang mampu membuat relaksasi meningkat. Berdasarkan penelitian yang telah dilakukan oleh Andriani (2015) tentang pengaruh latihan $S D B$ terhadap penurunan kadar gula darah pada pasien Diabetes Melitus tipe 2, mengatakan bahwa ada pengaruh latihan terapi Slow Deep Breathing terhadap menurunnya kadar gula didalam darah pada pasien Diabetes Melitus tipe 2. Latihan nafas lambat dan dalam jika dilakukan secara terus-menerus dapat membuat respon saraf simpatik menurun dan respon saraf parasimpatik meningkat, efek stress berkurang, meningkatan kesehatan fisik dan mental, frekuensi pernafasan dan kardiovaskuler meningkat, (Kiran, 2005 dalam Andriani, 2015) .

Berdasarkan uraian latar belakang diatas, saya ingin mengangkat studi literatur pengaruh Slow Deep Breathing (SDB) terhadap kadar gula darah pada penderita Diabetes Melitus tipe 2.

\section{Metode}

Data dikumpulkan dengan menggunakan studi pustaka, dengan cara menelusuri hasil publikasi ilmiah pada google scholar dalam rentang tahun 20152020. Hasil kemudian di analisis lalu disimpulkan.

\section{Hasil}

Berdasarkan dari hasil pencarian literatur dari berbagai artikel/jurnal yang telah ditemukan, ada 7 jurnal yang sesuai dengan kriteria inklusi. Penelitian tersebut menjelaskan tentang pengaruh Slow Deep Breathing (SDB) terhadap kadar gula darah pada penderita Diabetes Melitus.
Berdasarkan hasil penelitian yang telah dilakukan oleh Sukesi et al (2015) tentang Slow Deep Breathing terhadap kontrol kadar gula darah pada pasien DM tipe 2 di SMC RS Telogorejo dengan tujuan penelitian untuk mengetahui pengaruh latihan Slow Deep Breathing terhadap kontrol kadar gula darah pada pasien DM Tipe II menggunakan desain penelitian kuasi eksperimen pretest-posttest control group responden sebanyak 30 orang yaitu 15 responden pada kelompok intervensi dan 15 responden pada kelompok control dan data dikumpulkan sejak bulan januari-februari 2015. Karakteristik demografi pasien dikumpulkan meliputi jenis kelamin, usia, pendidikan, pekerjaan, dan IMT.Kadar gula darah dinilai dengan menggunakan alat Glukometer. Kelompok intervensi diberi perlakuan SDB selama 6 hari dengan frekuensi 3x selama 10 menit, sebelum makan sedangkan kelompok kontrol diobservsi tanpa dilakukan SDB, dan menunjukkan hasil bahwa pada kelompok intervensi mempunyai perbedaan kadar gula darah setelah dan sebelum diberikan terapi. Sedangkan, pada kelompok kontrol tidak terjadi perbedaan nilai yang cukup besar di karenakan tidak diberikan terapi.

Menurut hasil penelitian yang telah dilakukan Siswanti et al (2017) tentang perbandingan pengaruh kombinasi senam $\mathrm{dm}$ dan slow deep breathing $(\mathrm{sdb})$ dengan kombinasi senam $\mathrm{dm}$ dan progressive muscle relaxation (pmr) terhadap kadar glukosa darah (kgd) pada klien dm tipe 2 di puskesmas welahan 1 kabupaten jepara dengan tujuan penelitian untuk mengetahui pengaruh senam DM dan Slow Deep Breathing (SDB) dengan senam DM dan Progressive Muscle Relaxation (PMR) terhadap kadar glukosa darah (KGD) pada pasien DM tipe 2 di Puskesmas Welahan 1 Kabupaten Jepara menggunakan metode penelitian quasi eksperimental dengan desain penelitian pre and post test group design.Responden sebanyak 33 orang yang terbagi menjadi tiga kelompok, yaitu kelompok Slow Deep Breathing (SDB), kelompok Progressive Muscle Relaxation (PMR) dan kelompok kontrol. Teknik sampling yang digunakan yaitu teknik purposive sampling. Pengumpulan data dilakukan sejak 15-22 mei 2016. Teknik pengumpulan data menggunakan lembar observasi. Analisis data menggunakan uji paired T-test dan Independent T-test dengan tingkat kepercayaan 95\%, dan menunjukkan hasil bahwa ada pengaruh yang cukup besar pada kelompok intervensi 
sebelum dan setelah diberikan terapi, dengan selisih 38,18 . Sedangkan nilai kadar gula darah pada kelompok kontrol sebelum dan setelah, yaitu dengan selisih 6,41.

Penelitian yang dilakukan oleh Siswanti \& Suwarto (2019) tentang Slow Deep Breathing terhadap perubahan kadar glukosa pasien Diabetes Melitus dengan tujuan penelitian untuk mengetahui pengaruh Slow Deep Breathing (SDB) terhadap kadar glukosa darah (KGD) pada pasien DM tipe 2 di puskesmas Welahan 1 Kabupaten Jepara menggunakan jenis penelitian kuasi eksperiment dengan desain pre test dan post test two group responden sebanyak 34 orang terdiri dari 17 orang kelompok intervensi dan 17 orang kelompok kontrol. Teknik sampling yang digunakan yaitu teknik random sampling. Pengumpulan data dilakukan pada tahun 2019, karakteristik demografi pasien dikumpulkan meliputi umur, jenis kelamin, dan lama sakit. Pada kelompok intervensi sebelum dan setelah dilakukan SDB diukur kadar gula darahnya, sedangkan pada kelompok kontrol sebelum dan setelah tanpa adanya terapi diukur kadar gula darahnya, dan menunjukkan hasil bahwa Slow Deep Breathing yang diberikan selama 15 menit dalam 2x sehari selama 2 minggu dengan hasil kadar gula darah sebelum diberikan terapi Slow Deep Breathing yaitu 208,47 mg/dl, dan kadar gula darah sesudah diberikan terapi SDB yaitu 170,29 mg/dl. Dan Maka dapat ditarik kesimpulan bahwa terdapat pengaruh yang cukup besar terapi SDB terhadap kadar gula darah pada penderita DM tipe 2.

Berdasarkan penelitian yang telah dilakukan oleh Indriyani \& Ambrawati (2017) tentang terapi relaksasi nafas dalam (Deep Breathing) dalam menurunkan kadar gula darah pada pasien Diabetes Melitus II dengan tujuan penelitian untuk menggambarkan dan mendeskripsikan terapi relaksasi teknik nafas dalam (deep breathing) untuk menurunkan kadar gula darah pada pasien Diabetes Melitus tipe 2 menggunakan metode penulisan rancangan studi kasus evaluasi mengenai terapi relaksasi teknik nafas dalam. Responden terbagi menjadi 2 kelompok yaitu responden 1 dan responden 2 , yang dilakukan 15 menit dalam $3 x$ sehari selama 3 hari. Pengumpulan data dilakukan sejak 26-28 juli 2017. Karakteristik demografi pasien dikumpulkan meliputi usia, lama menderita, riwayat luka, turgor kulit, dan CRT. Teknik pengumpulan data melalui wawancara dan observasi secara langsung kepada responden yaitu melakukan pemeriksaan GDS sebelum dilakukan relaksasi nafas dalam selama 15 menit dalam 3x sehari kemudian diakhir sesi kadar glukosa darah diukur kembali kemudian disajikan dalam bentuk desktiptif, dan mengatakan hasil bahwasanya setelah diberikan implementasi selama 3 hari, dilakukan pemantauan GDS rutin setiap harinya, lalu dilakukan pemeriksaan kembali. Hasil yang diperoleh yaitu terjadinya penurunan kadar gula darah pada responden 1 yaitu $381 \mathrm{Mg} / \mathrm{dl}$ dan pada responden 2 yaitu $282 \mathrm{Mg} / \mathrm{dl}$.

Penelitian yang dilakukan oleh Nusantoro \& Listyaningsih (2018) tentang pengaruh SDB (Slow Deep Breathing) terhadap tingkat kecemasan dan kadar glukosa darah pada penderita Diabetes Mellitus dengan tujuan penelitian untuk mengetahui pengaruh SDB (Slow Deep Breathing) terhadap tingkat kecemasan dan kadar glukosa darah pada penderita Diabetes Mellitus menggunakan metode penelitian quasy exsperiment dengan pre and post test with control group design responden sebanyak 40 orang yaitu 20 responden kelompok intervensi dan 20 responden kelompok control. Teknik sampling yang digunakan yaitu teknik simpel random sampling. Pengumpulan data dilakukan sejak bulan april-juni 2018, karakteristik demografi pasien dikumpulkan meliputi usia, jenis kelamin, pendidikan, lama menderita DM. Pada kelompok intervensi diberi perlakuan SDB 2x dalam seminggu selama 4 minggu sedangkan kelompok kontrol diobservasi tanpa dilakukan SDB, dan hasilnya menunjukkan terjadi penurunan GDP pada kelompok intervensi, yaitu sebelum Slow Deep Breathing sebesar 223,75 dan sesudah Slow Deep Breathing sebesar 197,40..Sedangkan pada kelompok kontrol GDP terjadi peningkatan yaitu sebelum sebesar 215,55 dan sesudah sebesar 231,60.

Penelitian yang dilakukan oleh Yulianti \& Armiyanti (2019) tentang kombinasi relaksasi nafas dalam dan murottal surah ar-rahman menurunkan gula darah sewaktu pada pasien dm tipe ii dengan tujuan penelitian menganalisis pengaruh kombinasi relaksasi nafas dalam dan murottal penurunan Gula Darah Sewaktu (GDS) penderita diabetes melitus tipe II di wilayah kerja puskesmas Kedungmundu Semarang menggunakan eksperimental dengan desain eksperimen semu (quasy eksperimen), dengan rancangan yaitu three group pre test and post test. Responden sebanyak 30 orang yang terbagi menjadi 3 kelompok intervensi, kelompok pertama diberikan intervensi relaksasi nafas dalam, kelompok kedua 
diberikan intervensi murottal dan kelompok ketiga diberikan intervensi kombinasi relaksasi nafas dalam dan murottal dengan tiap kelompok 10 orang.Teknik sampling yang digunakan yaitu teknik purposive sampling dan random sampling. Dengan kriteria inklusi yaitu penderita diabetes melitus tipe II dengan GDS $\geq 200 \mathrm{mg} / \mathrm{dl}$, Islam, usia 35-75 tahun, kondisi sadar, bersedia menjadi responden, dan tidak obesitas. Pengumpulan data dilakukan sejak 18-28 juni 2019, karakteristik demografi pasien dikumpulkan meliputi usia, lama menderita, dan jenis kelamin, pendidikan. Instrumen yang digunakan untuk mengukur hemodinamik (Tekanan darah \& denyut nadi) dan gula darah sewaktu responden adalah sphygmomanometer digital yang terkalibrasi dan glukometer digital terkalibrasi. Alat yang digunakan untuk murottal adalah MP3 surah ar-rahman yang didengarkan menggunakan headphone. Intervensi kombinasi relaksasi nafas dalam dan murottal diawali intervensi relaksasi nafas dalam yang dilakukan selama 3 detik selama 6 menit 7 detik, setelah itu terapi murottal selama 13 menit 53 detik. Pengukuran gula darah sewaktu dilakukan sebelum dan sesudah dilakukan terapi, dan menunjukkan hasil bahwa pada ketiga kelompok sebelum dan sesudah diberikan intervensi yang banyak terjadi penurunan KGD ialah kelompok kombinasi murottal dan relaksasi nafas dalam, ditunjukkan dengan GDS menurun sebanyak 23,93\%, sedangkan pada kelompok relaksasi nafas dalam saja hanya turun sebanyak 9,97\%, dan pada kelompok murottal saja hanya turun 2,56\%. Karena adanya respon relaksasi, sehingga glukosa darah menjadi turun.

Penelitian yang telah dilakukan oleh Lestari, et al (2016) tentang pengaruh kombinasi progressive muscle relaxation dengan slow deep breathing terhadap kadar gula darah penderita diabetes di desa sambirejo plupuh sragen dengan tujuan penelitian untuk mengetahui pengaruh kombinasi terapi progresive muscle relaxation dengan Slow Deep Breathing terhadap kadar gula darah pada penderita diabetes menggunakan desain penelitian one group pre-post test quasi eksperiment (eksperimen semu). Responden sebanyak 32 orang, pengambilan sampel menggunakan teknik teknik total sampling. Pengumpulan data dilakukan sejak bulan juli 2016, karakteristik demografi pasien dikumpulkan meliputi jenis kelamin, usia, dan pekerjaan. Instrumen yang digunakan adalah alat cek glukometer dan lembar observasi. Kadar gula darah diukur sebelum dan setelah dilakukan terapi, dan menunjukkan hasil bahwa setelah dilakukan terapi dan dilakukan kembali pengecekan KGD terdapat perbedaan KGD sebelum dan sesudah yaitu sekitar 3-7 mg/dl, bahkan ada juga sampai $26 \mathrm{mg} / \mathrm{dl}$. Dapat ditarik kesimpulan, bahwa ada pengaruh kombinasi terapi Progresive Muscle Relaxation (PMR) dengan terapi SDB terhadap kadar gula didalam darah pada pasien Diabetes Melitus.

\section{Pembahasan}

Diabetes Melitus merupakan penyakit yang terjadi saat tubuh tidak mampu menggunakan insulin dengan baik, atau karena pankreas sudah tidak mampu untuk memproduksi insulin. Tidak mampu menghasilkan insulin atau menggunakannya secara maksimal mengakibatkan kadar gula didalm darah menjadi meningkat (hiperglikemia). Jika kadar gula di dalam darah tinggi dalam jangka panjang, dapat mengakibatkan kegagalan berbagai organ dan jaringan, dan kerusakan pada tubuh (IDF, 2019)

Teknik relaksasi merupakan bentuk terapi seperti memberikan aba-aba untuk memejamkan mata, dan konsentrasi hanya pada pernafasan sehingga tercipta keadaan yang tenang dan nyaman. Merenggangnya otot tubuh menjadi rileks dan santai dapat menciptakan perasaan yang nyaman dan tenang (Suyono, dkk. 2016).

Slow Deep Breathing adalah teknik bernapas secara dalam, lambat, dan rileks yang dilakukan secara sadar yang mampu memberikan respon relaksasi. Menurut Nipa (2017), Slow Deep Breahing juga adalah teknik relaksasi yang sederhana dimana paru-paru menghirup oksigen sebanyakbanyaknya.

Berdasarkan dari penelitian yang dilakukan Sukesi et al (2015), Siswanti \& Suwarto (2019), Nusantoro \& Listayaningsih (2018), Indirayanti \& Ambrawati (2017) menunjukkan kadar gula didalam darah menurun pada kelompok intervensi setelah dilakukan terapi Slow Deep Breathing selama $\geq 10$ menit dalam $2 x$ sehari, sedangkan tidak terjadi penurunan yang signifikan pada kelompok kontrol. Dan dari hasil penelitian yang dilakukan Lestari et al (2016), Siswanti et al (2017), Yulianti \& Armiyanti (2019) menunjukkan bahwa kadar gula darah menurun setelah dilakukan SDB selama $\leq 10$ menit tetapi dengan adanya penambahan terapi Progresive Muscle Relaxation (PMR) atau dengan terapi murottal surah Ar-Rahman.

Slow Deep Breathing ini dilakukan dengan mengatur posisi responden senyaman mungkin 
dengan duduk atau berbaring. Setelah itu, kedua tangan responden diminta untuk diletakkan di atas perut. Lalu, menganjurkan menarik nafas secara dalam dan perlahan melalui hidung selama tiga detik, saat menarik nafas rasakan perut mengembang. Kemudian, responden diminta untuk menahan napasnya selama tiga detik. Lalu, hembuskan napas melalui mulut secara pelan selama 6 detik dan merasakan perut bergerak ke arah bawah. Responden diminta untuk mengulanginya kembali selama 10 menit. Latihan Slow Deep Breathing ini dilakukan selama $2 x$ sehari yaitu pagi hari, dan sore hari (Tarwoto, 2015 dalam Latuconsina, 2019). Menurut Kiran (2005) dalam Andriani (2015) Dengan melakukan Latihan nafas lambat dan dalam secara sering dapat membuat respon saraf parasimpatis meningkat dan respon saraf simpatik menurun, frekuensi kardiovaskuler dan pernafasan meningkat, stress berkurang.

Relaksasi napas dalam mampu mengirimkan sinyal ke otak dan juga sistem limbik yang mengendalikan aktivitas tubuh, misalkan emosi, bangun, rasa lapar, tidak tidur, dan pengaturan mood. Saraf simpatis bekerja saat Individu sedang melakukan aktivitas tubuh. Sedangkan, saat sedang rileks/beristirahat maka yang akan bekerja adalah saraf parasimpatis. Saat saraf simpatis menurun, pembuluh darah menjadi lebih elastis dan sirkulasi darah lebih lancar sehingga membuat pernapasan menjadi lebih lancar, tubuh menjadi hangat, melancarkan sistem metabolisme, dan kerja jantung lebih ringan.

Dalam proses metabolisme, insulin mempunyai peran yang penting. Dalam keadaan normal, insulin berfungsi untuk memasukkan glukosa dalam sel untuk menghasilkan energi. Tetapi pada penderita DM tipe 2, jumlah insulinnya tidak cukup atau keadaan insulin yang dihasilkan tidak bagus (resistensi insulin). Sehingga karena adanya kelainan di dalam sel walaupun reseptornya ada dan insulinnya juga ada, pintu masuk ke dalam sel tidak mampu terbuka. Sehingga gula darah tidak mampu untuk masuk ke dalam sel untuk di bakar (dimetabolisme) (Soegondo, et al, 2018). Dengan menurunnya metabolisme akan terjadi penurunan proses glukogenolisis glukoneogenesis, dan glukogenesis. Saat proses tersebut menurun, kebutuhan akan insulinpun menurun. Jika insulin menurun, maka kadar gula didalam darah juga ikut menurun.

\section{Kesimpulan}

Berdasarkan hasil studi literatur dari ke-7 jurnal terkait penelitian ini menunjukkan bahwa ada pengaruh Slow Deep Breathing terhadap penurunan kadar gula di dalam darah setelah dilakukan $\geq 10$ menit selama $2 x$ sehari dan dapat dilakukan $\leq 10$ menit tetapi dikombinasikan dengan terapi Progresive Muscle Relaxation (PMR) atau dengan terapi murottal surah Ar-Rahman.

\section{Referensi}

Andriani Putu Risna. 2015. Pengaruh Latihan Slow Deep Breathing Terhadap Penurunan Kadar Gula Darah pada Pasien Diabetes Mellitus Tipe 2. Denpasar

ADA, 2019. American Diabetes Association, STANDARS OF MEDICAL CARE IN DIABETES-2019.

Dinkes Kota Makassar. 2019. Profil Dinas Kesehatan Kota Makassar tahun 2018.

IDF, 2019. Online Version Of DIABETES ATLAS 9th Edition 2019. Diakses tanggal 14 januari 2020 dari https://www.diabetesatlas.org/data/en/country/94/id.html dan http://www.diabetesatlas.org/data/en/world/

IDF. 2019. Online Version of IDF Diabetes Atlas 9th edition 2019. Diakses Tanggal 18 Januari 2020 https://www.idf.org/aboutdiabetes/type-2-diabetes.html I

Indriyani Rizki Maulida, \& Ambarwati. 2017. Terapi Relaksasi Teknik Nafas Dalam (Deep Breathing) Dalam Menurunkan Kadar Gula Darah Pada Pasien Diabetes Mallitus II. Jawa Tengah. Jurnal Profesi Keperawatan Vol.4 No.2

Latuconsina Janiba. 2019. Standar Operasional Prosedur (SOP) Slow Deep Breathing. Unoversitas Esa Unggul.

Nusantoro Agik Priyo, Listyaningsih Kartika Dian. 2018. Pengaruh SDB (Slow Deep Breathing) Terhadap Tingkat Kecemasan dan Kadar Glukosa Darah Pada Penderita Diabetes Melitus. Surakarta. Vol. II No 4

Riskesdas. 2018. Hasil Utama Riskesdas 2018. Badan Penelitian dan Pengembangan Kesehatan. 
Seogondo Sidartawan, Soewondo Pradana, \& Subekti Imam. 2018. Penatalaksanaan Diabetes Melitus Terpadu. Jakarta. Balai penerbit FKUI.

Siswantia Heny, Kurniati Tri, \& Supriyatna Nana. 2017. Perbandingan Pengaruh Kombinasi Senam DM dan Slow Deep Breathing (SDB) dengan Kombinasi Senam Dm dan Progressive Muscle Relaxation (Pmr) Terhadap Kadar Glukosa Darah (KGD) Pada Klien Dm Type 2 Di Puskesmas Welahan I Kabupaten Jepara Jawa Tengah, Tahun 2016. Jawa Tengah. Indonesia Jurnal Perawat. Vol.2 No.1

Siswanti Hery, \& Suwarto Tri. 2019. Slow Deeb Breathing Terhadap Perubahan Kadar Glukosa Pasien Diabetes Melitus. Jawa Tengah. Universitas Muhammadiyah Kudus.

Sukesi, Ismonah, \& Arif M.Syamsul. 2015. Slow Deeb Breathing Terhadap Kontrol Kadar Gula Darah Pada Pasien DM Tipe 2 Di SMC RS Telogorejo. Semarang.

Suyono, Triyono, \& Handarini M. Dany. 2016. Keefektifan Teknik Relaksasi untuk Menurunkan Stres Akademik Siswa SMA. Malang. Jurnal Pendidikan Humaniora Vol. 4 No. 2 